\title{
Soil Oxygen Limits Microbial Phosphorus Utilization in Humid Tropical Forest Soils
}

\author{
Avner Gross ${ }^{1,3, *}$, Jennifer Pett-Ridge ${ }^{2}$ and Whendee L. Silver ${ }^{1}$ \\ 1 Department of Environmental Science, Policy, and Management, University of California, \\ Berkeley, CA 94720, USA; wsilver@berkeley.edu \\ 2 Physical and Life Sciences Directorate, Lawrence Livermore National Laboratory, \\ Livermore, CA 94550, USA; pettridge2@llnl.gov \\ 3 Department for Geography and Environmental Development, Ben Gurion University of the Negev, \\ Beer-Sheva 8410501, Israel \\ * Correspondence: avner.gross@bgu.ac.il
}

Received: 9 October 2018; Accepted: 21 November 2018; Published: 29 November 2018

\begin{abstract}
Soil phosphorus (P) availability is of special interest in many humid tropical forests, especially those on highly weathered, iron (Fe)- and aluminum (Al)-rich soils where P often limits net primary productivity. Phosphorus cycling is partly dependent on the ability of microbes to compete for $\mathrm{P}$ with $\mathrm{Fe}$ and $\mathrm{Al}$ minerals, which strongly bind P. Soil $\mathrm{P}$ availability is also indirectly affected by soil redox conditions due to its effects on microbial activity and reductive dissolution of Fe oxides that may weaken Fe-O-P sorption strength. Here, we explored P sorption, soil Fe (II) concentrations, soil $\mathrm{CO}_{2}$ production, organic and inorganic $\mathrm{P}$ pools, and microbial biomass $\mathrm{P}$ in tropical soils that typically experience frequent low redox (valley soils), or fluctuating redox conditions (slope soils). Soils from both topographic positions were pre-incubated under oxic or anoxic headspaces and then amended with a mixture of $\mathrm{P}$ (as orthophosphate) and carbon ( $\mathrm{C}$, as acetate, to maintain microbial activity) and incubated in the dark for $24 \mathrm{~h}$. Phosphorus sorption to the mineral phase occurred on a time scale of seconds to minutes in valley and slope soils, reflecting strong abiotic P sorption capacity. Valley soils were characterized by inherently higher Fe(II) concentrations and lower respiration rates. Under anoxic headspaces, Fe(II) concentrations increased 3-to 5-fold in the both soils. Soil respiration and microbial $\mathrm{P}$ utilization declined significantly in both soils under anoxic conditions, regardless of Fe(II) concentrations. Microbial P concentrations were highest when slope soils were incubated under an oxic headspace, despite the high $\mathrm{P}$ sorption under these conditions. Our results suggest that microbial $\mathrm{P}$ utilization is indirectly limited by low $\mathrm{O}_{2}$ availability and that microbes are able to effectively compete with minerals for $\mathrm{P}$ under Fe-oxidizing conditions. These results emphasize the central role of soil microorganisms in regulating $\mathrm{P}$ availability, even in the presence of strong abiotic sorption capacity.
\end{abstract}

Keywords: phosphorus availability; microbial biomass; tropical soils; iron reduction; anoxic conditions

\section{Introduction}

Phosphorus (P) is thought to constrain net primary productivity (NPP) in humid tropical forests growing on highly weathered soils rich in Fe and Al minerals [1,2]. Phosphorus serves as a key regulator of plant growth, organic matter turnover, heterotrophic respiration and microbial activity in these ecosystems [1-6]. Because tropical forests store about a quarter of the global terrestrial C stock $[7,8]$, understanding controls on $\mathrm{P}$ availability can improve our capacity to model how tropical ecosystems will respond to global change [9]. One of the primary reasons for the low biological availability of $\mathrm{P}$ in these ecosystems is the high concentration of Fe (hydr)oxides, which can strongly 
sorb P $[10,11]$. In humid tropical forests and other soils with high P sorption, soil microorganisms must compete for $\mathrm{P}$ with the mineral phase to sustain their growth and activity $[12,13]$. However, our understanding of the factors that shape competition for $\mathrm{P}$ between the biological and geochemical components of humid tropical soils is limited.

Theory dictates that sorption dynamics of $\mathrm{P}$ are regulated in part by soil redox conditions (Figure 1). In tropical forest soils rich in Fe-(hyd)oxides, Fe(III) becomes the dominant terminal electron acceptor when $\mathrm{O}_{2}$ becomes depleted [14], a relatively common occurrence in fine-textured humid tropical forest soils $[15,16]$. The reductive dissolution of Fe minerals may release sorbed $\mathrm{P}$ and decrease $\mathrm{P}$ sorption strength, thus increasing the biological availability of P [17-20]. In turn, when soils become aerated, soluble Fe species are reoxidized. Iron oxidation increases P sorption potential to the soil mineral phase [21], which may decrease $\mathrm{P}$ availability to microorganisms. The effects of changing redox conditions on microbial activity in humid tropical soils is often overlooked in relation to soil P dynamics. Anoxic conditions may slow microbial respiration and activity [14,15,22], decreasing the ability of microbes to utilize P or compete with the mineral phase for soluble P. Soil aeration can stimulate microbial activity, and thus may drive an increase in microbial $\mathrm{P}$ requirements and assimilation potential [23] (Figure 1).

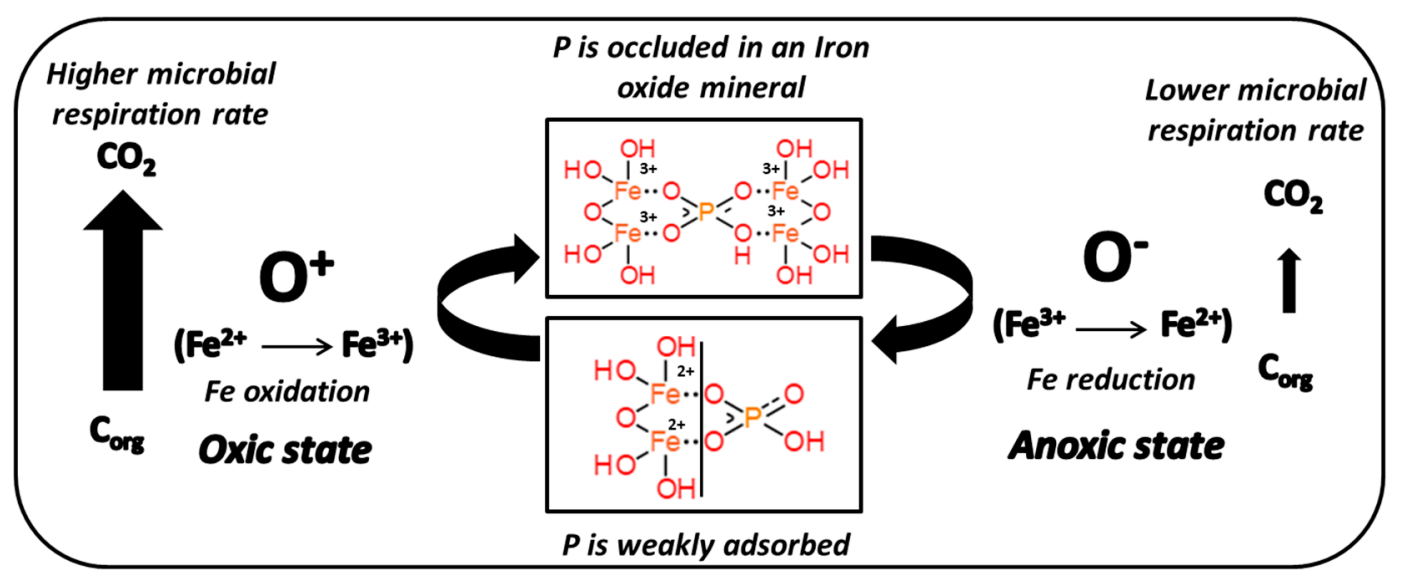

Figure 1. Schematic illustration of the expected effects of redox conditions on Fe oxidation state, P sorption and microbial activity.

Soil redox conditions can fluctuate on time scales of hours to days in humid tropical forest soils, where warm perhumid conditions and ample labile $\mathrm{C}$ drive high microbial activity and biological $\mathrm{O}_{2}$ demand, and warm, moist, finely textured soils slow $\mathrm{O}_{2}$ diffusion $[15,16]$. In such systems, soil redox tends to vary with topography; valley soils experience more frequent low redox conditions due to higher soil moisture content in lower topographic zones $[14,15,24]$. Thus, local topography may induce indirect controls on the soil $\mathrm{P}$ cycle and its biological availability through effects of redox on $\mathrm{Fe}$ and microbial activity.

Here we investigated how the relative redox sensitivity of microbial activity and Fe minerals regulate $\mathrm{P}$ distribution among the microbial, organic and mineral $\mathrm{P}$ pools in two highly weathered humid tropical forest soils incubated under different redox regimes. Valley and slope soils, that naturally have different redox dynamics and histories, were incubated under oxic and anoxic headspaces and amended with P (as orthophosphate) and C (as acetate, to maintain microbial activity). We tested the hypothesis that microbial biomass $\mathrm{P}$ is higher under anoxic versus oxic conditions due to decreased Fe-O-P sorption in frequently reduced soils. 


\section{Methods}

\subsection{Site Description}

Soils were collected from a humid tropical forest near the El Verde field station in the Luquillo Experimental Forest (LEF), Puerto Rico (Lat. $18^{\circ} 18^{\prime} \mathrm{N}$; Long. $65^{\circ} 50^{\prime} \mathrm{W}$ ). The site is part of the NSF-sponsored Long-Term Ecological Research program, a Critical Zone Observatory and part of the DOE-sponsored Next Generation Ecosystem Experiment-Tropics project. The mean annual temperature at the site is $23{ }^{\circ} \mathrm{C}$ and the mean annual rainfall is approximately $3500 \mathrm{~mm}$ with low seasonality [25]. The forest composition is relatively diverse, with approximately 168 tree species [26]. The soils are derived from basaltic to andesitic volcanoclastic sediments and classified as Ultisols. The landscape is highly dissected and characterized by short catenas (land surface distance of 10 to $30 \mathrm{~m}$ from ridge to valley); the short distances lead to similar clay-rich soil texture along catenas [27]. Soils are acidic (average $\mathrm{pH}$ is 5.0 and 5.2 in valley and slope soils, respectively, Table S1) and contain high concentrations of $\mathrm{Fe}$ and $\mathrm{Al}$ oxides [14]. Surface soils $(0-10 \mathrm{~cm})$ were sampled from four random $0.20 \mathrm{~m}^{2}$ plots each in a valley and an adjacent slope location (valley and slope positions within $10 \mathrm{~m}$ ). Plots within topographic zones were separated by $0.5-1 \mathrm{~m}$ intervals. These upland humid tropical forest soils experience periodic fluctuations in bulk soil $\mathrm{O}_{2}$ concentrations, oscillating from low $(<3 \%)$ to ambient $(21 \%)$ concentrations on time scales of hours to days $[15,16]$. Bulk soil $\mathrm{O}_{2}$ levels are strongly dependent on topography; valley soils experience high magnitude fluctuations and frequent low $\left(<3 \% \mathrm{O}_{2}\right)$ events while slopes are characterized by lower magnitude fluctuations, less frequent low redox events, and average $10-15 \% \mathrm{O}_{2}$ [15]. Soils in this ecosystem are not flooded; instead, low redox events are driven by an abundance of anoxic microsites that form from the combination of finely textured soils with low diffusion, high biological activity driven by abundant $C$ availability and high microbial activity, and warm, perhumid conditions [15,16,28]. Microbial function in these soils is highly dependent on bulk soil redox state and responds rapidly (minutes to hours) to changes in redox conditions [22,29-32]. Iron reduction rates and $\mathrm{Fe}(\mathrm{II})$ concentrations in valley soils are typically more than two orders of magnitude higher than in slopes [14]. In addition, reducible short-range order (oxy)hydroxides and organo-Fe complexes (measured as citrate/ascorbate-extractable Fe) and chelatable short-range order (oxy)hydroxides (measured as oxalate-extractable Fe) decline significantly from slope to valley positions, reflecting inherent differences in $\mathrm{O}_{2}$ concentrations [14].

\subsection{Incubation Experiment}

The soils were shipped to the University of California, Berkeley, immediately after sampling and kept at field moisture and room temperature (approximately $23^{\circ} \mathrm{C}$ ) during shipping and after arrival. Soils were gently homogenized by hand, and visible plant debris, rocks, and soil macrofauna were removed. To set up our incubations, we used a factorial experimental design that included soils from the four valley and four slope plots, incubated under oxic or anoxic conditions, and amended with either a P-plus- $\mathrm{C}$ solution ( $\mathrm{C}$ was added to facilitate utilization of the added $\mathrm{P}$ and maintain microbial activity similar to field-levels [17]) or distilled deionized (DI) $\mathrm{H}_{2} \mathrm{O}$ as a control (total sample size: $n=32$ ). Approximately $130 \mathrm{~g}$ of fresh soil from each plot of the slope soil and $150 \mathrm{~g}$ from each plot of the valley soil (oven dry weight equivalent (ODW) to $100 \mathrm{~g}$ dry soil, see soil moisture content in Table S1) were placed in a $487 \mathrm{~mL}$ air tight jar within $72 \mathrm{~h}$ after collection. Bulk oxic and anoxic conditions were created by flushing the jar headspace with either $\mathrm{CO}_{2}$-free air (oxic treatment) or $\mathrm{N}_{2}$ gas (anoxic treatment) for $15 \mathrm{~min}[30,33]$. To reach oxic or anoxic conditions before the addition of the substrate, jars were maintained under these headspace conditions for 10 days prior to the addition of solutions. Prior work suggests anoxic incubation of 10 days is long enough to remove most $\mathrm{O}_{2}$ from soil microsites and create large differences in the $\mathrm{O}_{2}$ levels between oxic and anoxic treatments [33]. After this pre-incubation period, 4 oxic and anoxic valley soils and 4 oxic and anoxic slope soils (a total of 16 jars) were amended with a mixture of $\mathrm{P}$ and $\mathrm{C}\left(80 \mu \mathrm{g} \mathrm{P}\right.$ g soil ${ }^{-1}+100 \mu \mathrm{g} \mathrm{C} \mathrm{g} \mathrm{soil}{ }^{-1}$ ODW dissolved in $\left.100 \mathrm{~mL} \mathrm{DI} \mathrm{H} \mathrm{H}_{2} \mathrm{O}\right)$ in the form of potassium phosphate $\left(\mathrm{KH}_{2} \mathrm{PO}_{4}\right.$, Sigma Aldrich St. Louis, $\left.\mathrm{MO}, \mathrm{USA}\right)$ ) 
and acetate (an easily fermentable substrate [17]). For the controls, $100 \mathrm{~mL}$ of $\mathrm{DI} \mathrm{H}_{2} \mathrm{O}$ was added to samples from the same topographic and headspace treatment combinations as described above ( $n=16$ jars). For the anoxic samples, the solutions were amended inside a glove box, after degassing with helium (He) to remove traces of $\mathrm{O}_{2}$. The added solutions contained similar $\mathrm{P}$ concentrations as is cycled through the microbial biomass on weekly time scales at this site $[17,18]$; the $C$ amendment was of the same order of magnitude as the dissolved organic $C$ concentrations previously measured in these soils [28]. After the soils were amended with substrates, they were incubated in the dark, outside (for the oxic soils) or inside a glove box (for the anoxic soils) for $24 \mathrm{~h}$ at $23^{\circ} \mathrm{C}$ to mimic the soil temperature at the field site. Samples were incubated under the same redox regime post substrate addition as they had experienced during the pretreatment period. After the 24-h incubation period, headspace $\mathrm{CO}_{2}$ concentrations were analyzed and soil subsamples were collected for Fe and P measurements.

\subsection{Iron Measurements}

Redox-sensitive Fe concentrations were measured immediately after the pre-incubation period and before the substrate additions using an $\mathrm{HCl}$ extraction. The $\mathrm{HCl}$ extraction ( $\mathrm{HCl}-\mathrm{Fe}$ ) provides an index of reactive, adsorbed and some solid phase Fe(II), and the reactive fraction of $\mathrm{Fe}(\mathrm{III})$ minerals [34], and is a good indicator of reducing conditions. For our extraction, $1 \mathrm{~g}$ ODW soil was shaken in $10 \mathrm{~mL}$ $0.5 \mathrm{M} \mathrm{HCl}$ for $2 \mathrm{~h}$ and filtered through $22-\mu \mathrm{m}$ filter paper. $\mathrm{Fe}(\mathrm{II})$ and $\mathrm{Fe}(\mathrm{III})$ concentrations in the $\mathrm{HCl}$ extracts were determined colorimetrically using the Ferrozine method [35]. For samples treated with an anoxic headspace, the extraction solutions were first degassed with He to remove traces of $\mathrm{O}_{2}$, and added to the soils in an anoxic glove box.

\subsection{Soil $\mathrm{CO}_{2}$ Measurements}

Immediately prior to substrate additions, the pre-incubation jars were flushed with either $\mathrm{CO}_{2}$ free air (for oxic pre-incubations) or $\mathrm{N}_{2}$ gas (for anoxic pre-incubations) to offset the $\mathrm{CO}_{2}$ that accumulated in the jar headspace during the pre-incubation period. Then, $24 \mathrm{~h}$ after the soils were amended with substrates and right before the soils were harvested for chemical analysis, two replicate $30 \mathrm{~mL}$ gas samples were collected from each jar headspace, and stored in pre-evacuated glass vials. Gas concentrations were measured on a gas chromatograph with a TCD detector (Shimadzu, Columbia, MD). A $\mathrm{CO}_{2}$ gas with a concentration of 997 ppm (PRAXAIR, Danbury, CT, USA) served as a standard. Air that was $\mathrm{CO}_{2}$-free (PRAXAIR, Danbury, CT, USA) served as the blank. The $\mathrm{CO}_{2}$ flux rate was calculated based on a two point linear interpretation of the two points over $24 \mathrm{~h}$ using the $\mathrm{CO}_{2}$ concentration in $\mathrm{CO}_{2}$-free air or $\mathrm{N}_{2}$ as a $\mathrm{T}_{\text {inital }}$, and our measured values at the end of the incubation as $\mathrm{T}_{\text {final }}$. Measured $\mathrm{CO}_{2}$ concentrations were corrected for dissolution based on the water content of the two soils.

\subsection{Phosphorus Measurements}

At the end of the 24-h incubation period, soil subsamples were collected for P analysis. The extraction solutions used for samples treated with an anoxic headspace were first degassed with He to remove traces of $\mathrm{O}_{2}$ and added to the soils in an anoxic glove box. For each incubation jar, two different inorganic $P$ pools were extracted sequentially from $5 \mathrm{~g}$ (ODW) of soil. In the first step, the soil resin $\mathrm{P}$ fraction (considered the $\mathrm{P}$ fraction that is most immediately available for uptake by soil microorganisms $[36,37])$ was extracted by shaking the soil on an orbital shaker with 4 squares of anion exchange resin membranes $(4 \times 1 \mathrm{~cm}, \mathrm{BDH}-55164)$ in $50 \mathrm{~mL}$ of DI- $\mathrm{H}_{2} \mathrm{O}$ for $24 \mathrm{~h}$. The $\mathrm{P}$ was later eluted from the resin by shaking the membranes for $12 \mathrm{~h}$ with $5 \mathrm{~mL}$ of $0.2 \mathrm{M} \mathrm{HNO}_{3}$ [38]. In the second step, P was extracted using $40 \mathrm{~mL}$ of $0.25 \mathrm{M} \mathrm{NaOH}$ and $50 \mathrm{mM} \mathrm{Na} 2$ EDTA from the same soil sample [39]. The $\mathrm{NaOH} \mathrm{P}$ fraction is thought to represent organic and inorganic $\mathrm{P}$ that is sorbed to secondary $\mathrm{Fe}$ and $\mathrm{Al}$ oxides and thus less immediately bioavailable to microorganisms (relative to resin $\mathrm{P}$ ). The $\mathrm{NaOH}$ extract was then digested in an autoclave with ammonium persulfate $\left(\left(\mathrm{NH}_{4}\right)_{2} \mathrm{~S}_{2} \mathrm{O}_{8}\right)$ [40] to determine the total $\mathrm{P}$ (organic plus inorganic). To calculate the amount of organic 
$\mathrm{P}$ in the $\mathrm{NaOH}$ extract, the concentration of $\mathrm{P}$ measured before digestion (assumed to be dominantly inorganic $\mathrm{NaOH}-\mathrm{P}$ ) was subtracted from the total $\mathrm{P}$ concentration measured after digestion.

We determined microbial $P$ on separate soil subsamples following the method of Kouno et al. [41], which is thought to be suitable for soils with high P sorption capacity. Briefly, $5 \mathrm{~g}$ of soil (ODW) was shaken for $24 \mathrm{~h}$ with $40 \mathrm{~mL} \mathrm{DI} \mathrm{H}_{2} \mathrm{O}$ and 4 resin strips (see above), and fumigated (or not) with $1 \mathrm{~mL}$ hexanol. Phosphorus was eluted from the resin strips as explained above. Microbial P was determined using the difference between the fumigated and unfumigated soils. Values were corrected for microbial $P$ that was not recovered during the fumigation because of incomplete lysis (using the common Kp correction factor of 0.4) [42]. To correct microbial $\mathrm{P}$ for the proportion of $\mathrm{P}$ that was sorbed by soil minerals and was not recovered by the resin strips, (an important step in soils with high $\mathrm{P}$ sorption capacity [43]), $10 \mathrm{~g}$ of valley and slope soil subsamples were spiked with $50 \mu \mathrm{g} \mathrm{P} \mathrm{g}^{-1}$ soil (as $\mathrm{KH}_{2} \mathrm{PO}_{4}$ ). We found that an average of 35 and $55 \%$ of the added $\mathrm{P}$ was recovered by the resin in valley and slope soils, respectively. These soil-specific corrections were included in the microbial $\mathrm{P}$ calculation together with the $\mathrm{Kp}$ factor. Inorganic $\mathrm{P}$ concentrations in each of the extracts were determined colorimetrically [44] in duplicate, with an average difference between duplicates of $1.3 \%$. We used the ratio of the resin- $\mathrm{P}$, microbial $\mathrm{P}, \mathrm{NaOH}$ inorganic $\mathrm{P}$ and $\mathrm{NaOH}$ organic $\mathrm{P}$ to the sum of the $\mathrm{P}$ pools to calculate relative $\mathrm{P}$ partitioning.

\subsection{Single Point Sorption Test}

To assess the maximum potential sorption rate of $\mathrm{P}$ to the mineral phase, we used a single point P sorption test [45]. Briefly, $500 \mathrm{~mL}$ of solution containing $50 \mathrm{mg} \mathrm{P} \mathrm{L}{ }^{-1}$ (as $\left.\mathrm{KH}_{2} \mathrm{PO}_{4}\right), 0.002 \mathrm{M} \mathrm{CaCl}_{2}$, and 30 drops of toluene (to inhibit microbial activity) were added to $20 \mathrm{~g}$ of air-dried soil from 3 of the 4 plots sampled from both the valley and slope locations ( $n=6$, no anoxic or oxic pretreatment) and shaken on an orbital shaker. Four replicate $5 \mathrm{~mL}$ subsamples were collected after $5 \mathrm{~min}$, and again after $1,3,6,12,24$, and $48 \mathrm{~h}$. The subsamples were centrifuged for $10 \mathrm{~min}$ and filtered through a grade 42 $(2.5 \mu \mathrm{m})$ ashless Whatman filter paper. The $P$ in these soil extracts was determined colorimetrically [44]. The percentage of $\mathrm{P}$ sorbed to the mineral phase was calculated as the amount of P lost from the soil solution as a percentage of the total $\mathrm{P}$ added.

\subsection{Statistical Analysis}

Effects of hillslope position (slope, valley), substrate addition (P plus $\mathrm{C}$, control), and redox treatments (oxic, anoxic) on $\mathrm{P}, \mathrm{Fe}$, and soil $\mathrm{CO}_{2}$ production were determined by three-way analysis of variance (ANOVA) followed by Tukey's tests for pairwise comparisons. Data were checked and met the assumptions for ANOVA. We used linear regression analyses to explore the relationship between microbial $\mathrm{P}$ and soil $\mathrm{CO}_{2}$ flux rates. All statistical analyses were conducted in $\mathrm{R}$ (version 3.3.3). Values reported in the text are means plus or minus standard errors unless otherwise noted. Statistical significance was determined as $p<0.05$ unless otherwise noted.

\section{Results}

\subsection{Iron Species}

Initial $\mathrm{Fe}$ (II) concentrations, measured on field-fresh soils, were significantly higher in the valley than in the slope soils, ranging from $340 \pm 10 \mu \mathrm{g} \mathrm{Fe}(\mathrm{II}) \mathrm{g}$ soil $^{-1}$ to $53 \pm 9 \mu \mathrm{g} \mathrm{Fe}(\mathrm{II}) \mathrm{g}$ soil $^{-1}$, respectively (Table S1, $p<0.01$ ). Initial Fe(III) concentrations were one to two orders of magnitude higher than $\mathrm{Fe}(\mathrm{II})$ at both sites and were significantly higher in valley $\left(5700 \pm 190 \mu \mathrm{g} \mathrm{Fe} \mathrm{g} \mathrm{soil}{ }^{-1}\right)$ than in slope soils $\left(1100 \pm 70 \mu \mathrm{g} \mathrm{Fe} \mathrm{g} \mathrm{soil}^{-1}, p<0.01\right.$, Table S1). At the end of the oxic incubation, HCl-Fe(II) concentrations were significantly higher in the valley soils than slope soils $\left(200 \pm 9 \mu \mathrm{g} \mathrm{Fe} \mathrm{g} \mathrm{soil}{ }^{-1}\right.$ and $45 \pm 20 \mu \mathrm{g} \mathrm{Fe} \mathrm{g} \mathrm{soil}{ }^{-1}$, respectively, $p<0.01$, Figure S1). In the valley soils, the $\mathrm{HCl}-\mathrm{Fe}(\mathrm{II})$ concentrations were 5 -times higher after incubating under anoxic conditions than under oxic, reaching values of $1100 \pm 70 \mu \mathrm{g} \mathrm{Fe} \mathrm{g} \mathrm{soil}{ }^{-1}$. In slope soils, $\mathrm{HCl}-\mathrm{Fe}(\mathrm{II})$ was a factor of 4 greater in the anoxic treatment 
compared to the oxic treatment, reaching values of $210 \pm 20 \mu \mathrm{g}$ Fe g soil ${ }^{-1}$ (Figure S1). Both effects were statistically significant $(p<0.01)$.

\subsection{Soil $\mathrm{CO}_{2}$ Production}

Soil $\mathrm{CO}_{2}$ production 24 -h after the substrates were added was significantly lower in valley soils than slope soils for all treatments (Figure $2 \mathrm{a}, \mathrm{b}$, Table $\mathrm{S} 2, p<0.001$ ). In both the valley and slope soil, $\mathrm{CO}_{2}$ production was significantly higher when amended with $\mathrm{P}+\mathrm{C}$ under the oxic headspace relative to the anoxic headspace $(p<0.05)$, and in soils that received $\mathrm{P}+\mathrm{C}$ amendments relative to the controls $(p<0.001)$. For the slope soils, the equivalent amount of added acetate $\mathrm{C}$ respired after $24 \mathrm{~h}$ of incubation was $89.9 \pm 8.4 \%$ in the oxic incubation, as compared to only $55.4 \pm 6.1 \%$ in the anoxic incubation. In the valley, the equivalent amount of added substrate $C$ respired was $6.3 \pm 1.6 \%$ and $3.6 \pm 0.3 \%$ in the oxic and anoxic incubation, respectively.
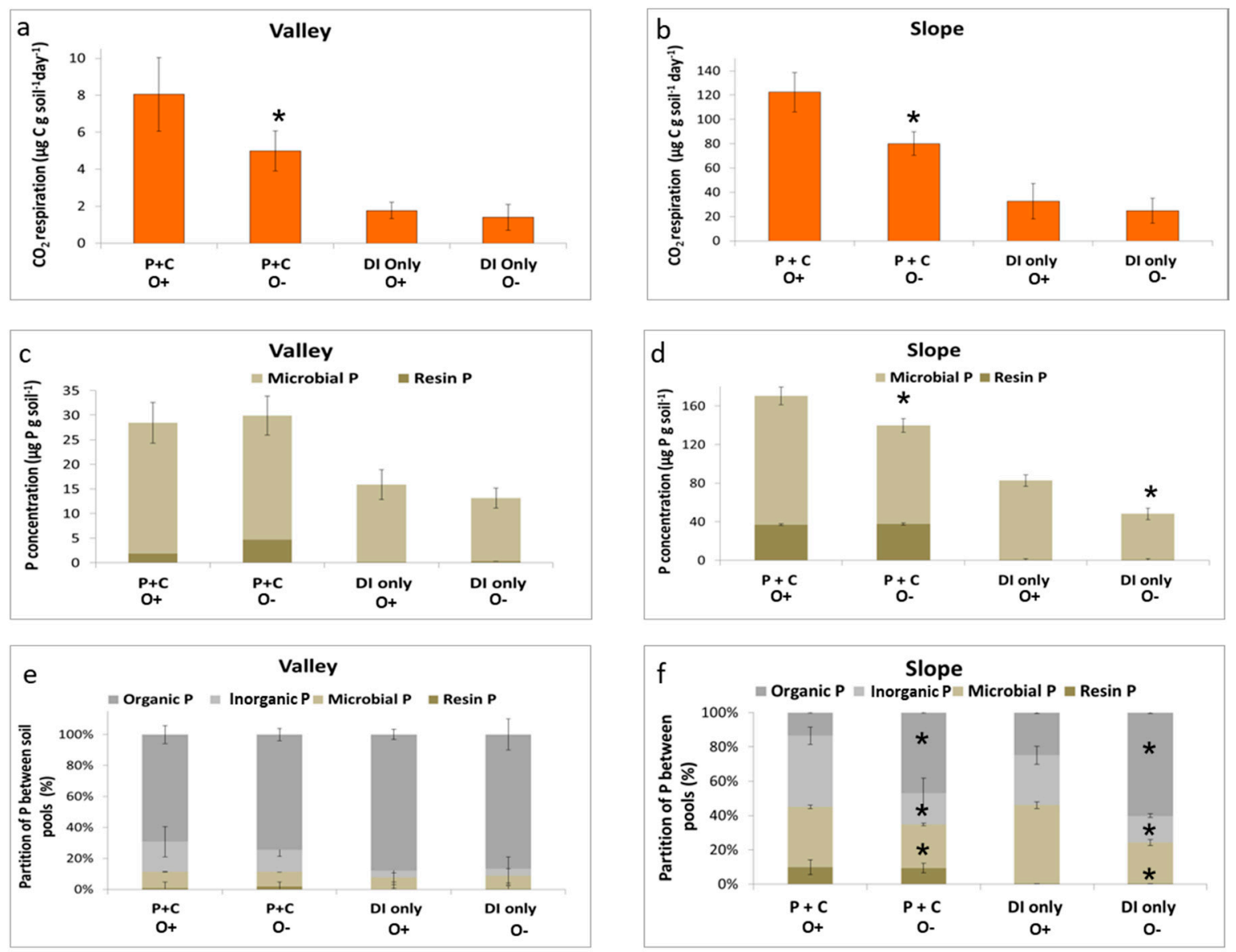

Figure 2. $\mathrm{CO}_{2}$ respiration $\left(\mu \mathrm{g} \mathrm{C}\right.$ g soil $^{-1}$ day $\left.^{-1}\right)$, microbial and resin $\mathrm{P}$ concentrations $\left(\mu \mathrm{g} \mathrm{P} \mathrm{g} \mathrm{soil}{ }^{-1}\right)$, and partitioning of $\mathrm{P}$ between soil pools (expressed in \%) in two humid tropical forest soils: (a,c,e) valley soils, $(\mathbf{b}, \mathbf{d}, \mathbf{f})$ slope soils. Soils were pre-incubated under either an oxic $(\mathrm{O}+)$ or anoxic $(\mathrm{O}-)$ headspace and amended with $\mathrm{P}\left(\mathrm{KH}_{2} \mathrm{PO}_{4}\right)$ and $\mathrm{C}$ (acetate) or DI water (control). Note that the range of the Y-axis is different for the valley and slope in panels a b and c and d. An asterisk $\left(^{*}\right)$ designates statistically significant differences between oxic and anoxic treatments $(p<0.01) . n=4$ per treatment, per site.

\subsection{Phosphorus Pools}

Microbial P concentrations were significantly higher in slope soils relative to valley soils in all treatments (Figure 2c,d and Table S2). In valley soils, the P distributions between the resin extractable, microbial, $\mathrm{NaOH}$-organic, and -inorganic pools were not significantly affected by headspace treatment (Figure 2e and Table S2). Microbial P concentrations were significantly lower under an anoxic 
headspace in comparison to the oxic headspace $(p<0.01)$ in the slope soil (Figure $2 \mathrm{~d}$ ), decreasing from $133.4 \pm 10.0 \mu \mathrm{g} \mathrm{P} \mathrm{g} \mathrm{soil}{ }^{-1}$ to $102.0 \pm 7.0 \mu \mathrm{g} \mathrm{P} \mathrm{g} \mathrm{soil}{ }^{-1}$ in the $\mathrm{P}+\mathrm{C}$ amended soils and from $82.1 \pm 4.0 \mu \mathrm{g} \mathrm{P} \mathrm{g} \mathrm{soil}{ }^{-1}$ to $49.2 \pm 7.0 \mu \mathrm{g} \mathrm{P} \mathrm{g} \mathrm{soil}^{-1}$ in the control. In slope soils, the P distribution between the different $\mathrm{P}$ pools was significantly affected by headspace treatment (Figure $2 \mathrm{f}$ and Table S2). $\mathrm{NaOH}$-extractable organic $\mathrm{P}$ was significantly higher under anoxic conditions in comparison to oxic conditions in both the amended and control soils $(p<0.01$, Figure $2 \mathrm{f}$ and Table S2). In the slope, values increased from $59.1 \pm 11.2 \mu \mathrm{g} \mathrm{P} \mathrm{g} \mathrm{soil}{ }^{-1}$ to $188.3 \pm 24.7 \mu \mathrm{g} \mathrm{P} \mathrm{g} \mathrm{soil}{ }^{-1}$ and from $44.6 \pm 7.2 \mu \mathrm{g} \mathrm{P} \mathrm{g} \mathrm{soil}{ }^{-1}$ to $119.8 \pm 39.1 \mu \mathrm{g} \mathrm{P} \mathrm{g} \mathrm{soil}{ }^{-1}$ under oxic and anoxic conditions, respectively. In contrast, $\mathrm{NaOH}$-inorganic $\mathrm{P}$ was significantly lower under anoxic conditions in both the amended soils and the control, decreasing from $148.4 \pm 20.2 \mu \mathrm{g} \mathrm{P} \mathrm{g} \mathrm{soil}{ }^{-1}$ to $73.9 \pm 30.5 \mu \mathrm{g} \mathrm{P} \mathrm{g} \mathrm{soil}{ }^{-1}$ and from $52.2 \pm 9.6 \mu \mathrm{g} \mathrm{P} \mathrm{g} \mathrm{soil}^{-1}$ to $31.0 \pm 2.2 \mu \mathrm{g} \mathrm{P} \mathrm{g} \mathrm{soil}{ }^{-1}$ in valley and slope soils, respectively $(p<0.01$, Figure $2 \mathrm{f}$ and Table S2).

\subsection{Single Point P Sorption Test}

A single point sorption test (expressed in percentage) showed that after $5 \mathrm{~min}$ of incubation, $77 \pm 12 \%$ of the added $\mathrm{P}$ had been removed from solution in valley soils (Figure 3a) and $\mathrm{P}$ concentrations in the soil solution remained constant thereafter, from $5 \mathrm{~min}$ to $48 \mathrm{~h}$. In slope soils, the added $\mathrm{P}$ in solution declined by $45 \pm 3 \%$ after $5 \mathrm{~min}$, by $88 \pm 3 \%$ after $24 \mathrm{~h}$, and by $94 \pm 5 \%$ after 48 h (Figure 3b).

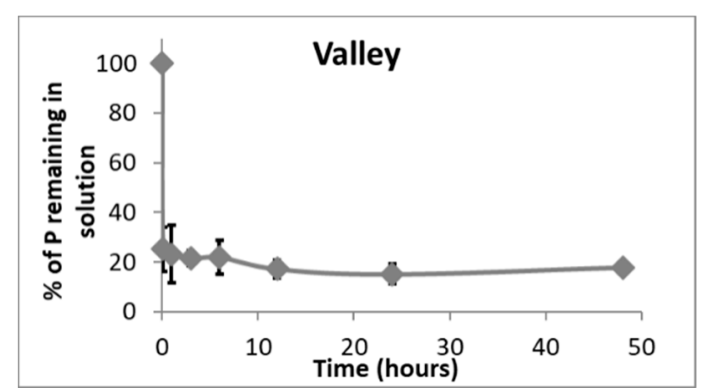

(a)

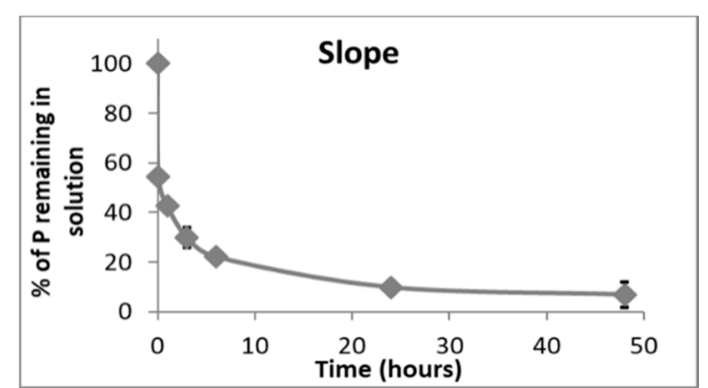

(b)

Figure 3. Single point sorption test for wet tropical forest soils from a valley (a) and slope location (b) in the Luquillo Experimental Forest, Puerto Rico. Plots shows the percent of added P (50 mg P L $\left.{ }^{-1}\right)$ remaining in the soil solution over the course of $48 \mathrm{~h}$.

\section{Discussion}

We sought to explore how the redox sensitivity of Fe pools and microbial biomass and activity affected soil $\mathrm{P}$ availability in humid tropical forest soils with different redox histories. It is generally assumed that $\mathrm{Fe}(\mathrm{II})$ has lower bonding strength for $\mathrm{P}$ than $\mathrm{Fe}(\mathrm{III})$, thus soils with greater potential to reduce Fe were expected to increase the biological availability of P. We found significantly higher $\mathrm{HCl}$-extractable $\mathrm{Fe}(\mathrm{II})$ concentrations in valley soils than in slope soils (where bulk redox conditions tend to oscillate between more/less oxic), and this effect persisted throughout our incubation experiment. Anoxic incubation increased Fe(II) concentrations from soils of both topographic positions, but concentrations reached the highest levels in the valley soils. The greater capacity for Fe(II) production during anoxic conditions in valley soils suggests a geochemical legacy effect for the soils in this topographic position. The higher Fe(III) in valley soils is probably due to the accumulation of Fe transported in dissolved form and reprecipitated in valleys during short-term oxic events or due to the generation of Fe(III) minerals under anoxic events [46]. Repeated reduction of Fe-rich soils can increase the proportion of short-range order, reactive Fe minerals [47], which likely contributed to the soil's responsiveness here.

Short-term soil respiration data provided evidence that anoxic conditions inhibited microbial activity and/or overall biomass size. Soil $\mathrm{CO}_{2}$ production after $24 \mathrm{~h}$ was an order of magnitude lower in the valley soils relative to the slope soils, and the respired $\mathrm{C}$ (as a proportion of the acetate-C 
added or as a result of a priming effect) was also significantly lower in the valley soils. It is possible that persistence of anoxic microsites in these well-aggregated soils inhibited microbial activity, even when soils were exposed to an oxic headspace [48]. Anoxic conditions significantly lowered microbial respiration in both valley and slope soils when $\mathrm{P}+\mathrm{C}$ was added, but the decrease was much greater in the slope soils, supporting the anoxic microsite hypothesis mentioned above. The significantly higher $\mathrm{Fe}(\mathrm{II})$ concentrations and significantly lower $\mathrm{CO}_{2}$ production rates that we measured in the valley soils under both oxic and anoxic headspaces relative to slope soils follows the widely accepted hypothesis that anoxic environments favor Fe reduction [46,49], but at the same time likely constrain aerobic respiration of $\mathrm{CO}_{2}$, at least in the short term [14,22].

We measured higher microbial $\mathrm{P}$ in oxic conditions, in contrast to the common hypothesis that microbial biomass $\mathrm{P}$ should be higher under anoxic conditions due to decreased Fe-O-P sorption and higher $\mathrm{P}$ availability in frequently reduced soils. Both valley and slope soils had very high $\mathrm{P}$ sorption potential under oxic conditions. This implies that microbes may have a relatively short window to assimilate any P released during anoxic events before it becomes chemically sorbed to $\mathrm{Fe}$ or $\mathrm{Al}$ oxides (or potentially to soil organic matter) under oxic conditions. If $\mathrm{P}$ sorption/desorption was the primary control on biological P uptake, then microbial $\mathrm{P}$ assimilation should be higher in anoxic soils, assuming the microbial biomass size is equal. This is because low redox conditions are generally assumed to result in a decrease in Fe-O-P sorption strength and an increase in available $\mathrm{P}$ (Figure 1) $[17,18,20]$. As a result, the NaOH-Pi (which is indicative to inorganic $\mathrm{P}$ that is bound to $\mathrm{Fe}$ ) is expected to decline concurrently with an increase in the resin and microbial P pools. While we measured lower overall $P$ sorption in valley soils where low redox events are common, we found significantly lower microbial $\mathrm{P}$ concentrations than in the slope soils, despite lower sorption potential. Furthermore, an anoxic headspace led to lower microbial $\mathrm{P}$ in slope soils, even when the soils were amended with $\mathrm{P}$ and $\mathrm{C}$. The lower microbial P under anoxic conditions may also reflect, in part, a decline in overall microbial biomass, caused by limited $\mathrm{O}_{2}$. In the slope soils, $\mathrm{NaOH}$ Pi declined significantly under anoxic conditions, probably reflecting the release of Fe-bound P. However, the decrease in sorbed $\mathrm{Pi}$ was not matched by an increase in microbial $\mathrm{P}$, indicating that microbes were unable to utilize the liberated $\mathrm{P}$ under low $\mathrm{O}_{2}$ availability. Under more aerated conditions, microbes were better able to compete for $\mathrm{P}$ even though Fe-O-P sorption strength generally increases under oxidized conditions $[10,21]$. This explains the higher microbial $P$ that we measured under the oxic headspace in slope soils (and in the slope in general) when compared to the valley soils.

The increased concentrations of $\mathrm{NaOH}$-organic $\mathrm{P}$ found in slope soils under anoxic conditions were close to the values we measured in the highly reduced valley soils. These high values likely reflect the accumulation of $\mathrm{NaOH}$-organic $\mathrm{P}$ compounds as was reported previously in a nearby site [19]. This could be the result of (1) a downregulation in the synthesis of extracellular phosphatases under anoxic conditions [50], (2) an increase in microbial death that drove the release of cell-internal organic P compounds to the soil [10], or (3) a reduction in the ability of soil microbes to mine P from organic matter, which reflects lower microbial activity or lower overall biomass. A combination of these factors likely contributed to the higher $\mathrm{NaOH}$-organic $\mathrm{P}$ measured under anoxic conditions. The control of soil redox conditions on microbial biomass $\mathrm{P}$ affected the general distribution of $\mathrm{P}$ in the slope soils between oxic and anoxic headspace treatments, and between the slope and valley soils in both treatments. This is evidence for the key role microbes play in mobilizing P in highly weathered, Fe oxide-rich humid tropical forest soils [13,38,51-53]. Apart from microbially-mediated processes, inorganic reactions such as liberation of organic $\mathrm{P}$ compounds occluded or sorbed to oxidized Fe minerals $[17,20,21]$ may have also contributed to accumulation of organic $P$ we observed.

In summary, we found lower overall microbial $\mathrm{P}$ in soils with a legacy of low redox conditions, and less sensitivity of valley soils to anoxic headspace conditions relative to slope soils which are more frequently aerated. Microbial P declined under anoxic conditions on slopes. The generally lower soil respiration of valley soils and the decline of soil respiration under anoxic conditions on slopes suggests that the size or activity of the microbial biomass $\mathrm{P}$ pool may be limited by $\mathrm{O}_{2}$ availability in 
this ecosystem, at least in the short-term. However, further investigation is needed to understand the exact mechanisms. Our results suggest that low redox conditions, whether chronic (as in the valley) or periodic (on slopes) influences the soil P cycle through constraints imposed on the amounts of P cycled through the microbial biomass.

Supplementary Materials: The following are available online at http:/ /www.mdpi.com/2571-8789/2/4/65/s1, Figure S1: Soil Fe (II) concentrations, Table S1: Soil properties, Table S2: P concentrations and soil CO2 production.

Author Contributions: A.G. and W.L.S. designed the study. A.G. performed the incubation experiments and analyzed the samples. A.G., J.P.-R., and W.L.S. wrote the paper.

Funding: This research was funded by a US-Israeli Binational Agricultural Research and Development postdoctoral fellowship (BARD) to A. Gross, grants from the Department of Energy (TES-DE-FOA-0000749) and National Science Foundation (DEB-1457805) to W.L. Silver, and a DOE OBER Genomic Sciences Early Career Research Program award to J. Pett-Ridge (SCW1478). Additional support was provided by the NSF Luquillo Critical Zone Observatory (EAR-0722476) to the University of New Hampshire and the NSF Luquillo LTER (DEB-0620910) to the University of Puerto Rico. W.L. Silver received additional support from the USDA National Institute of Food and Agriculture; McIntire Stennis project CA- B-ECO-7673-MS. Work at Lawrence Livermore National Laboratory (LLNL) was performed under the auspices of the U.S. Department of Energy by LLNL under Contract DE-AC52-07NA27344.

Acknowledgments: We thank Heather Dang, Summer Ahmed, Christine O'Connell, Yang Lin, and Ryan Salladay for assistance in the lab, in the field, and for providing advice.

Conflicts of Interest: The authors declare no conflicts of interest.

\section{References}

1. Cleveland, C.C.; Townsend, A.R.; Taylor, P.; Alvarez-Clare, S.; Bustamante, M.M.; Chuyong, G.; Dobrowski, S.Z.; Grierson, P.; Harms, K.E.; Houlton, B.Z.; et al. Relationships among net primary productivity, nutrients and climate in tropical rain forest: A pan-tropical analysis. Ecol. Lett. 2011, 14, 1313-1317. [CrossRef]

2. Vitousek, P.M.; Porder, S.; Houlton, B.Z.; Chadwick, O.A. Terrestrial phosphorus limitation: Mechanisms, implications, and nitrogen-phosphorus interactions. Ecol. Appl. 2010, 20, 5-15. [CrossRef] [PubMed]

3. Nottingham, A.T.; Turner, B.L.; Stott, A.W.; Tanner, E.V. Nitrogen and phosphorus constrain labile and stable carbon turnover in lowland tropical forest soils. Soil Boil. Biochem. 2015, 80, 26-33. [CrossRef]

4. Cleveland, C.C.; Townsend, A.R. Nutrient additions to a tropical rain forest drive substantial soil carbon dioxide losses to the atmosphere. Proc. Natl. Acad. Sci. USA 2006, 103, 10316-10321. [CrossRef] [PubMed]

5. Kaspari, M.; Garcia, M.N.; Harms, K.E.; Santana, M.; Wright, S.J.; Yavitt, J.B. Multiple nutrients limit litterfall and decomposition in a tropical forest. Ecol. Lett. 2008, 11, 35-43. [CrossRef] [PubMed]

6. Cleveland, C.C.; Townsend, A.R.; Schmidt, S.K. Phosphorus limitation of microbial processes in moist tropical forests: Evidence from short-term laboratory incubations and field studies. Ecosystems 2002, 5, 0680-0691. [CrossRef]

7. Pan, Y.; Birdsey, R.A.; Phillips, O.L.; Jackson, R.B. The structure, distribution, and biomass of the world's forests. Annu. Rev. Ecol. Evol. Syst. 2013, 44, 593-622. [CrossRef]

8. Jobbágy, E.G.; Jackson, R.B. The vertical distribution of soil organic carbon and its relation to climate and vegetation. Ecol. Appl. 2000, 10, 423-436. [CrossRef]

9. Reed, S.C.; Yang, X.; Thornton, P.E. Incorporating phosphorus cycling into global modeling efforts: A worthwhile, tractable endeavor. New Phytol. 2015, 208, 324-329. [CrossRef] [PubMed]

10. Miller, A.J.; Schuur, E.A.; Chadwick, O.A. Redox control of phosphorus pools in Hawaiian montane forest soils. Geoderma 2001, 102, 219-237. [CrossRef]

11. Sanchez, P.A. Properties and Management of Soils in the Tropics. Soil Sci. 1977, 124, 187. [CrossRef]

12. Ayaga, G.; Todd, A.; Brookes, P.C. Enhanced biological cycling of phosphorus increases its availability to crops in low-input sub-Saharan farming systems. Soil Boil. Biochem. 2006, 38, 81-90. [CrossRef]

13. Olander, L.P.; Vitousek, P.M. Biological and geochemical sinks for phosphorus in soil from a wet tropical forest. Ecosystems 2004, 7, 404-419. [CrossRef]

14. Hall, S.J; Silver, W.L. Reducing conditions, reactive metals, and their interactions can explain spatial patterns of surface soil carbon in a humid tropical forest. Biogeochemistry 2015, 125, 149-165. [CrossRef] 
15. Silver, W.L.; Lugo, A.E.; Keller, M. Soil oxygen availability and biogeochemistry along rainfall and topographic gradients in upland wet tropical forest soils. Biogeochemistry 1999, 44, 301-328. [CrossRef]

16. Liptzin, D.; Silver, W.L.; Detto, M. Temporal dynamics in soil oxygen and greenhouse gases in two humid tropical forests. Ecosystems 2011, 14, 171-182. [CrossRef]

17. Chacon, N.; Silver, W.L.; Dubinsky, E.A.; Cusack, D.F. Iron reduction and soil phosphorus solubilization in humid tropical forests soils: The roles of labile carbon pools and an electron shuttle compound. Biogeochemistry 2006, 78, 67-84. [CrossRef]

18. Liptzin, D.; Silver, W.L. Effects of carbon additions on iron reduction and phosphorus availability in a humid tropical forest soil. Soil Boil. Biochem. 2009, 41, 1696-1702. [CrossRef]

19. Peretyazhko, T.; Sposito, G. Iron(III) reduction and phosphorous solubilization in humid tropical forest soils. Geochim. Cosmochim. Acta 2005, 69, 3643-3652. [CrossRef]

20. Lin, Y.; Bhattacharyya, A.; Campbell, A.N.; Nico, P.S.; Pett-Ridge, J.; Silver, W.L. Phosphorus fractionation responds to dynamic redox conditions in a humid tropical forest soil. J. Geophys. Res. Biogeosci. 2018, 123, 3016-3027. [CrossRef]

21. Parfitt, R.L.; Atkinson, R.J.; Smart, R.S. The mechanism of phosphate fixation by iron oxides. Soil Sci. Soc. Am. J. 1975, 39, 837-841. [CrossRef]

22. McGroddy, M.; Silver, W.L. Variations in belowground carbon storage and soil CO2 flux rates along a wet tropical climate gradient. Biotropica 2000, 32, 614-624. [CrossRef]

23. Menezes-Blackburn, D.; Giles, C.; Darch, T.; George, T.S.; Blackwell, M.; Stutter, M.; Shand, C.; Lumsdon, D.; Cooper, P.; Wendler, R.; et al. Opportunities for mobilizing recalcitrant phosphorus from agricultural soils: A review. Plant Soil 2018, 427, 5-16. [CrossRef]

24. Liptzin, D.; Silver, W.L. Spatial patterns in oxygen and redox sensitive biogeochemistry in tropical forest soils. Ecosphere 2015, 6, 1-14. [CrossRef]

25. Harris, N.L.; Lugo, A.E.; Brown, S.; Heartsill-Scalley, T. Luquillo experimental forest: Research history and opportunities. In Experimental Forest and Range EFR-1; USDA Forest Service: Washington, DC, USA, 2012.

26. Wadsworth, F.H. Ordenación forestal en las montañas de LuquilloForest management in the Luquillo mountains. Caribb. For. 1951, 12, 115-132.

27. O'Connell, C.S.; Ruan, L.; Silver, W.L. Drought drives rapid shifts in tropical rainforest soil biogeochemistry and greenhouse gas emissions. Nat. Commun. 2018, 9, 1348. [CrossRef] [PubMed]

28. Hall, S.J.; Silver, W.L. Iron oxidation stimulates organic matter decomposition in humid tropical forest soils. Glob. Chang. Boil. 2013, 19, 2804-2813. [CrossRef] [PubMed]

29. Bhattacharyya, A.; Campbell, A.N.; Tfaily, M.M.; Lin, Y.; Silver, W.L.; Nico, P.S.; Pett-Ridge, J. Redox fluctuations control the coupled cycling of iron and carbon in tropical forest soils. BioRxiv 2018. [CrossRef] [PubMed]

30. Pett-Ridge, J.; Firestone, M.K. Redox fluctuation structures microbial communities in a wet tropical soil. Appl. Environ. Microbiol. 2005, 71, 6998-7007. [CrossRef] [PubMed]

31. Pett-Ridge, J.; Petersen, D.G.; Nuccio, E.; Firestone, M.K. Influence of oxic/anoxic fluctuations on ammonia oxidizers and nitrification potential in a wet tropical soil. FEMS Microbiol. Ecol. 2013, 85, 179-194. [CrossRef] [PubMed]

32. Pett-Ridge, J.; Silver, W.L.; Firestone, M.K. Redox Fluctuations Frame Microbial Community Impacts on N-cycling Rates in a Humid Tropical Forest Soil. Biogeochemistry 2006, 81, 95-110. [CrossRef]

33. Hall, S.J.; Silver, W.L.; Timokhin, V.I.; Hammel, K.E. Lignin decomposition is sustained under fluctuating redox conditions in humid tropical forest soils. Glob. Chang. Boil. 2015, 21, 2818-2828. [CrossRef] [PubMed]

34. Fredrickson, J.K.; Zachara, J.M.; Kennedy, D.W.; Dong, H.; Onstott, T.C.; Hinman, N.W.; Li, S.M. Biogenic iron mineralization accompanying the dissimilatory reduction of hydrous ferric oxide by a groundwater bacterium. Geochim. Cosmochim. Acta 1998, 62, 3239-3257. [CrossRef]

35. Viollier, E.; Inglett, P.W.; Hunter, K.; Roychoudhury, A.N.; Van Cappellen, P. The ferrozine method revisited: Fe (II)/Fe (III) determination in natural waters. Appl. Geochem. 2000, 15, 785-790. [CrossRef]

36. Cooperband, L.R.; Gale, P.M.; Comerford, N.B. Refinement of the anion exchange membrane method for soluble phosphorus measurement. Soil Sci. Soc. Am. J. 1999, 63, 58-64. [CrossRef]

37. Qian, P.; Schoenau, J.J. Practical applications of ion exchange resins in agricultural and environmental soil research. Can. J. Soil Sci. 2002, 82, 9-21. [CrossRef] 
38. Gross, A.; Turner, B.L.; Wright, S.J.; Tanner, E.V.; Reichstein, M.; Weiner, T.; Angert, A. Oxygen isotope ratios of plant available phosphate in lowland tropical forest soils. Soil Boil. Biochem. 2015, 88, 354-361. [CrossRef]

39. Turner, B.L.; Engelbrecht, B.M.J. Soil organic phosphorus in lowland tropical rain forests. Biogeochemistry 2010, 103, 297-315. [CrossRef]

40. Tiessen, H.; Moir, J.O. Characterization of available P by sequential extraction. In Soil Sampling and Methods of Analsis; CRC Press: Baca Ratoon, FL, USA, 1993; pp. 75-86.

41. Kouno, K.; Tuchiya, Y.; Ando, T. Measurement of soil microbial biomass phosphorus by an anion-exchange membrane method. Soil Boil. Biochem. 1995, 27, 1353-1357. [CrossRef]

42. Brookes, P.; Powlson, D.S.; Jenkinson, D.S. Measurement of microbial biomass phosphorus in soil. Soil Boil. Biochem. 1982, 14, 319-329. [CrossRef]

43. Bilyera, N.; Blagodatskaya, E.; Yevdokimov, I.; Kuzyakov, Y. Towards a conversion factor for soil microbial phosphorus. Eur. J. Soil Biol. 2018, 87, 1-8. [CrossRef]

44. Murphy, J.; Riley, J.P. A modified single solution method for the determination of phosphate in natural waters. Anal. Chim. Acta 1962, 27, 31-36. [CrossRef]

45. Henry, P.; Smith, M.F. Two-step approach to determining some useful phosphorus characteristics of South African soils: A review of work done at the ARC-Institute for Soil, Climate and Water. South Afr. J. Plant Soil 2006, 23, 64-72. [CrossRef]

46. Weber, K.A.; Achenbach, L.A.; Coates, J.D. Coates, Microorganisms pumping iron: Anaerobic microbial iron oxidation and reduction. Nat. Rev. Microbiol. 2006, 4, 752. [CrossRef] [PubMed]

47. Thompson, A.; Rancourt, D.G.; Chadwick, O.A.; Chorover, J. Iron solid-phase differentiation along a redox gradient in basaltic soils. Geochim. Cosmochim. Acta 2011, 75, 119-133. [CrossRef]

48. Keiluweit, M.; Gee, K.; Denney, A.; Fendorf, S. Anoxic microsites in upland soils dominantly controlled by clay content. Soil Boil. Biochem. 2018, 118, 42-50. [CrossRef]

49. Quantin, C.; Becquer, T.; Rouiller, J.H.; Berthelin, J. Redistribution of metals in a New Caledonia Ferralsol after microbial weathering. Soil Sci. Soc. Am. J. 2002, 66, 1797-1804. [CrossRef]

50. Hall, S.J.; Treffkorn, J.; Silver, W.L. Breaking the enzymatic latch: Impacts of reducing conditions on hydrolytic enzyme activity in tropical forest soils. Ecology 2014, 95, 2964-2973. [CrossRef]

51. Turner, B.L.; Lambers, H.; Condron, L.M.; Cramer, M.D.; Leake, J.R.; Richardson, A.E.; Smith, S.E. Soil microbial biomass and the fate of phosphorus during long-term ecosystem development. Plant Soil 2013, 367, 225-234. [CrossRef]

52. Turner, B.L.; Wright, J.S. The response of microbial biomass and hydrolytic enzymes to a decade of nitrogen, phosphorus, and potassium addition in a lowland tropical rain forest. Biogeochemistry 2014, 117, 115-130. [CrossRef]

53. Wood, T.E.; Matthews, D.; Vandecar, K.; Lawrence, D. Short-term variability in labile soil phosphorus is positively related to soil moisture in a humid tropical forest in Puerto Rico. Biogeochemistry 2016, 127, $35-43$. [CrossRef]

(C) 2018 by the authors. Licensee MDPI, Basel, Switzerland. This article is an open access article distributed under the terms and conditions of the Creative Commons Attribution (CC BY) license (http:// creativecommons.org/licenses/by/4.0/). 